\title{
ICT in a Digital Era a Means of Entrepreneurship and Wealth Creation for the Girl Child
}

\author{
${ }^{1}$ Emmanuel I. Tukur, ${ }^{2}$ Eneh, A. Hyacinth, ${ }^{3}$ Arinze Uchechukwu, ${ }^{4}$ Daniel D. Wisdom \\ 5 Migdad B. Umar \& ${ }^{6}$ Joshua B. Hassan \\ 1Department of Mathematics/ComputerScience, Adamu Augie College of Education, Argungu Kebbi State \\ ${ }^{283}$ Department of Computer Science, University of Nigeria, Nsukka (UNN), Nsukka, Enugu State, Nigeria \\ ${ }^{4}$ Department of Computer Science, Ahmadu Bello University (ABU) Zaria, Kaduna State, Nigeria \\ ${ }^{5}$ Department of Computer Science, Kaduna State University (KASU), Kaduna State Nigeria \\ ${ }^{6}$ Department of Computer Science, Federal University Oye Ekiti, Ekiti State, Nigeria \\ E-mails: udabah@gmail.com, 2agozieeneh@gmail.com; 3arinzechukwu@gmail.com; \\ 4marbell051@gmail.com; 5danieldaudawisdom1@gmail.com
}

\begin{abstract}
Information and Communication Technology, ICT have a direct impact on raising living standards and improving the quality of life of the poor. There is no doubt that countries that are making major progress in the area of wealth creation are those in the fore-front of developing, deploying and exploiting ICT within their economy and society. Also, Entrepreneurship is increasingly being accepted as an important and innovative strategy for improving the livelihood and economic independence of young people.However, ICT is believed to help the youths develop varied skills including entrepreneurial skills. This paper examines the role of ICT and Telecommunication as an Entrepreneurship, Wealth Creation and Implication for the Girl Child in Selected Science Secondary Schools in Kebbi State. The study adopted a descriptive survey design. The sample for the study consisted of 1,200 female students from the six (6) Girls science secondary schools in Kebbi State. A Structured questionnaire was developed by the researchers to collect information from the sample. The data collected was analyzed using inferential statistics (T-test). The paper concludes that ICT has a great role in improving the standard of living.
\end{abstract}

Keywords: ICT, Telecommunications, Entrepreneurship and Wealth Creation.

Proceedings Reference Format

Emmanuel I. Tukur, Eneh, A. Hyacinth, Arinze Uchechukwu, Daniel D. Wisdom, Migdad B. Umar \& Joshua B. Hassan. (2021): ICT in a Digital Era a Means of Entrepreneurship and Wealth Creation for the Girl Child. Proceedings of the 27th iSTEAMS Multidisciplinary Innovations \& Technology Transfer (MINTT) Conference. Academic City University College, Accra, Ghana. June, 2021. Pp 221-230 www.isteams.net/ghana2021. DOI - https://doi.org/ 10.22624/AIMS/iSTEAMS-2021/N27P18

\section{INTRODUCTION}

Information and Communications Technology (ICT) or (Technologies) is an umbrella term that includes any communication device or application, encompassing: radio, television, cellular phones, computer and network hardware and software, satellite systems and so on, as well as the various services and applications associated with them, such as videoconferencing and distance learning. Fosters defines ICT as the group of technologies that is revolutionizing the handling of information and embodies a convergence of interest between electronics, computing and communication [1]. 


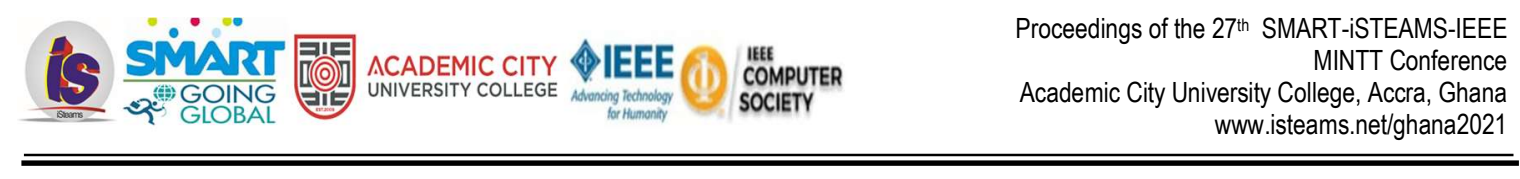

ICT is defined as the integration and utilization of computer technologies for the purpose of disseminating information to a target destination or consumer without the constraint of time and space [2]. ICT have the potential to combat poverty, be it rural or urban poverty. It will also foster sustainable development if appropriately deployed and made to address the diverse discrepancy in the ICT needs of people of all locations, age group, gender and economic status. ICT has become a potent force in transforming social, economic and political life globally. Women are often unsung heroine in the advancement of information technology (IT) especially in the developing nations like Nigeria where women are dramatically underrepresented in the ICT field.

There is increasing evidence that access to ICTs can have a direct impact on raising living standards and improving the quality of life of the poor. The indirect impact on poverty alleviation, through growth and productivity, has long been recognized. There is no doubt that: countries that are making major progress in the area of wealth creation are those in the fore-front of developing, deploying and exploiting ICTs within their economy and society. Women's Entrepreneurship Development (WED) is recognized by international organizations and governments worldwide as an important strategy for creating jobs, developing the economy, reducing gender inequality, and contributing to family wellbeing. Cultural boundaries and traditional belief system in Nigeria has hindered the start-up and growth of female-owned and managed enterprises. Female entrepreneurs are often underestimated and overlooked, and are also often stalled because of cultural barriers such as male/female role definitions that label women inherently inferior to men, especially in rural areas where there is a higher gender stereotyped perception of women, associating them with lack of confidence and assertiveness.

There are numerous possibilities for ICT to improve women's economic activities. Increased access to information is probably the greatest benefit that ICT can bring [3]. If women are able to use it productively, they can substantially acquire skills for life, create labour, improve their lives and increase their income. it is against this background that this paper seeks to investigate the roles of ICT and telecommunication as an entrepreneurship and wealth creation as well as the Implication for the girl child/woman in Northern Nigeria precisely in Kebbi State.

\subsection{Statement of the problem}

The girl child/woman in Northern Nigeria area of Kebbi State in particular is subjected to traditional believes and norms of the North as a result parents quickly shift responsibility to the husband as such subjecting them to early marriage, denial of western education and poverty [4]. Such a poor girl/woman is not protected from devoice after giving birth to about seven or more children sometimes there are even cases of devoiced just after about four to six months of marriage. At the event of death of her husband or devoice she is left with nothing to do to improve the standard of her living and that of her children and sometimes left at the mercy of her parents or forced to marry another man and abandon the seven children to the society thereby becoming street children (Almajiris).

\subsection{Objective of the Study}

The aim of this study is to increase the enrolment of girl child/woman in ICT and Telecommunication and to acquire lifelong skills for self-employment and letter as an entrepreneur or employer of labour respectively. 


\subsection{Hypothesis}

$\mathrm{H}_{01}$ : There is no significant relationship between the knowledge of ICT, Telecommunication and Entrepreneurship and wealth creation among women / girls in Kebbi State.

$\mathrm{H}_{02}$ : There is no significant difference between the knowledge of ICT and telecom among women / girls in Kebbi state.

$\mathrm{H}_{03}$ : There is no significant relationship between the knowledge of ICT and acquisition of skills for life among women /girls in Kebbi state.

\subsection{Significance of the Study}

Every research effort is a contribution to the existing body of knowledge in that particular area of studies hence the significance of this study must be recognized in this regard.

The study is expected to be of benefit to a number of groups; especially the Girl child/ Women in Northern Nigeria of Kebbi State in Particular to be able to acquire skills for life and prevent over dependence on their parents or husbands as well as create wealth and labour to improve the economy of their family and that of the Nation generally.

\subsection{Scope of the Study}

This study focused on The Role of ICT and Telecommunication as an Entrepreneurship and Wealth Creation. The research is confined to some selected Girls Science Secondary schools in Kebbi State.

\section{CONCEPTUAL CLARIFICATION OF ICT}

ICT is an electronic technology for collecting, storing, processing and communicating information [5]. ICT according to Butcher is categorized into two, namely: those which process information such as computer systems and those which disseminate information such as telecommunication system. To [6], ICT include all the different means, methods, tools that humans have used throughout history to help manage information, conduct business, and communicate with others and better understand the world around them.

\section{Telecommunications}

Telecommunication is the transmission of signs, signals, messages, words, writings, images and sounds or information of any nature by wire, radio, optical or other electromagnetic systems. Telecommunication occurs when the exchange of information between communication participants includes the use of technology. It is transmitted either electrically over physical media, such as $\underline{\text { cables}}$, or via electromagnetic radiation.

\section{Entrepreneurship}

The Concepts of entrepreneurship is about self-employment, which will generate employment opportunities to others that must work with him as he cannot work alone thereby becoming employer of labour. According to [7] Sees entrepreneurship as "the process of doing something new and/or something different for the purpose of creating wealth for the individual and adding value to society".[8] defines entrepreneurship as the art of turning an idea into a business. [9][11] Define an entrepreneur as a person who has possession of an enterprise, or venture, and assumes significant accountability for the inherent risks and the outcome of the enterprise. 


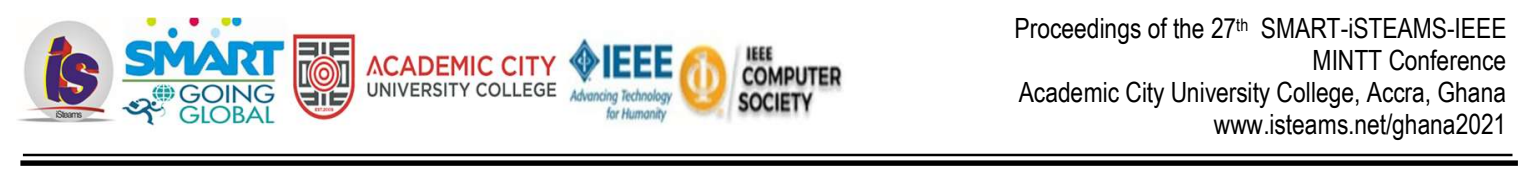

\section{Wealth}

The concept of 'wealth' varies among societies. Therefore, the word wealth means different things to different people. In its most narrow sense, wealth refers to abundance of anything. But generally, wealth refers to the stock of all assets net of liabilities that can contribute to people's wellbeing. In common language, the term "wealth" often connotes ownership of money and other financial assets, net of liabilities. Economists and statisticians often refer to wealth as the net value of marketable assets, including physical assets such as houses, land, and equipment, as well as financial assets.

\section{Wealth Creation}

Wealth creation involves the building of assets by means of careful investment, usually over a long period so as to achieve an income stream that will ensure a continuation of a high-quality lifestyle.[10]ln the same vain [11] state that wealth creation in simple terms, refers to economic growth and better standard of living for the individual, family or states.

\subsection{Roles of ICT and Telecommunications}

In the last two decades, ICTs have been regarded as a prerequisite for job and wealth creation. Organizations such as the UN, World Bank etc. have identified ICT as a driver for national economic development that delivers improvements in productivity, creates new channels for entertainment and services, and whole new industries and other social services to achieve poverty reduction.ICTs and the cyberspace have become a crucial ingredient for the survival of individuals, businesses and governments globally. ICTs cut across all sectors of our economy including the provisioning of essential services for good governance, agriculture, transportation, health and even basic delivery of goods and services and financial transactions. ICT is not only a game changer, it is a Revolution. In Nigeria, ICTs must be considered a critical key driver for social development and economic growth.

The role of ICT in entrepreneurship is manifold, ranging from facilitated communication between the two sides to online sales. IT systems affects the firm ' with products and services, markets, product cost, and product differentiation. Thus, the success of innovative firms critically depends on the implementation and creative use of IT [12]. Today's progress of ICT and other related technologies is making the global market closer to each individual and therefore increased volume and an online store. However, this way of doing business is still under-utilized, because of resentment of people towards art, because of lack of awareness of what opportunities are available to them. The use of information technology in the company is possible for increasing productivity, faster to share information between people and to have better communication between employees within the company. The high level of mobile phones usage in developing countries and increased availability of internet services have enabled many companies to expand their operations.

Hence, the role of ICT in facilitating job creation for the youths, especially developing countries, cannot be over emphasized. ICT can facilitate developing countries" ability to combat the several socio-economic challenges confronting them. Increasing access to information, through the power of the internet infrastructure, and creation of several innovative tools and accessories, could create several opportunities which can be exploited by entrepreneurs [13]. ICT has introduced new forms of entrepreneurship based on the use of information. These benefits of ICTs include increased in the pace and quality of innovations, as well as macroeconomic benefits such as per-capita GDP growth, job creation, and rapid improvements in labour and total factor productivity. ICT, along with education/training and research and development (R\&D), is one of the most important elements in building a platform for entrepreneurship and innovation. 


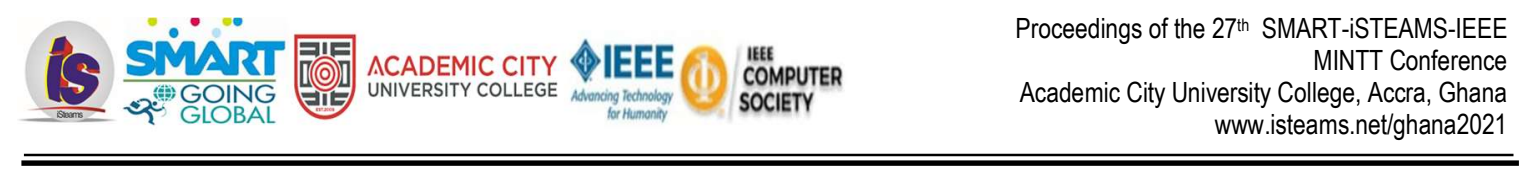

The positive contribution of ICT to economic growth and innovation in emerging and advanced countries has been repeatedly established through both quantitative and qualitative research. On a macroeconomic level, ICT usage has been shown to be correlated with global competitiveness, total factor productivity growth, increases in GDP, and many more direct economic benefits [14]. ICT has also been found to improve enterprise performance in emerging countries by increasing sales, employment, profitability, and labour and total factor productivity.

ICT supports entrepreneurship and innovation through: increasing interconnectedness and collaboration; allowing smaller, entrepreneurial companies to compete in global markets; reducing the cost of entry for new entrepreneurs; facilitating research diversification and interdisciplinary approaches; enhancing the ability of entrepreneurs to develop new business models, products, services, and processes; shortening product development cycles; providing new tools to create, organize, store, and transmit information; supporting disruptive business models that transform industries; and facilitating faster access to regional and international markets [15]. [16] listed some ICT entrepreneurial opportunities to include: selling telephone based services; young people as information intermediaries (accessing vast information on the internet and interpret it in the light of the local context); developing websites in local languages or facilitate communication between NGOs; use of e-mail to respond on behalf of program beneficiaries to feedback on specific local issues of concern to them; tele centres as income generators for young people; and income generation through cable television, among others.

ICT facilitates access to information, capital, markets and training needed to pursue a career or studies; increased participation in political processes, and recognition of youth as responsible citizens in today's society. Entrepreneurship which is enabled by access to technology, the internet and information is fast being positioned as a solution for youth employment. ICT therefore does not only facilitate entrepreneurship but there are also entrepreneurial opportunities in ICT. The youth must also develop their business skills in addition to the ICT expertise for the business established to thrive.

\section{WOMEN/GIRL CHILD AND ICT OPPORTUNITIES}

The ICT is a fast growing new technological era. ICT is inflowing fast in Nigeria both in education and in the job market but still in its infancy. ICT has opened global job market where people with competence can do jobs sitting in their own house anywhere in the world without going to or attending the work place [17]. There are numerous possibilities for IT to improve women's economic activities as well as increase access to information. Probably the greatest benefit that IT can bring. If women are able to use it productively, can substantially improve their livelihood as well as finance.

Studies have shown that the ICT era also known as the digital era have created various types of jobs from Chief Information Officer in big enterprises or government agencies to the computer shop operators since early 90 's. Vendors of hand held phones and their accessories are common sight in every community. There are various types of ICT based businesses such as document processing centres, cybercafé, computer training centres, computer services and repairs, hand set services and repairs, internet, programming, cable and satellite TV installations, etc. with very little take off funds. They are common vocations to empower youth [18][19]. 
A great number of women in developing countries, Nigeria in mostly engage in running small business. The most valuable application of IT for women small business owner is information, accessing information to facilitate their business, generating and disseminating information about it (Heeks n.d). There are many ways of using the internet to do business, from making contacts and checking prices to displaying goods and entering into contracts [20]. Women entrepreneurs in developing countries can secure gains from IT with little technical training ICT job has created avenue for jobs. Women could take up ICT job in various forms ranging from data entry, cyber café operators, technicians, programmers, web designers, computer engineers, data processing and analysis, and computer operators. These job opportunities are for both men and women. This is the age when ICT has created numerous job opportunities in the midst of non-ICT job scarcity [21][22].

\section{RESULTS AND DISCURSIONS}

\section{$\mathrm{H}_{01}$ : There is no significant relationship between the knowledge of ICT, Telecommunication and Entrepreneurship and wealth creation among women/girls in Kebbi State.}

\begin{tabular}{|l|l|l|l|l|l|l|l|}
\hline Option & Mean $(\bar{X})$ & SD & N & Df & $\begin{array}{l}\text { Calculated } \\
\text { Value }\end{array}$ & $\begin{array}{l}\text { Critical } \\
\text { Value }\end{array}$ & Remark \\
\hline Yes & 812.2 & 200.3 & 1150 & 4 & 1.75 & 2.78 & \\
\hline No & 337.8 & 302.3 & & & & & \\
\hline
\end{tabular}

$<0.05=2.78$

The above table is the analysis of the hypothesis that there is no significant relationship between wealth creation, Entrepreneurship and the knowledge of ICT and Telecommunications among women/girl child in Kebbi state. The questionnaire items were used to addresse the findings. Since the calculated value is less than the critical value, we accept the null hypothesis that, there is no significant relationship between the Entrepreneurship, wealth creation and knowledge of ICT and Telecommunication among women/girls in Kebbi State [23][24].

$\mathrm{H}_{02}$ : There no significant difference between the knowledge of ICT and telecom among women/ girls in Kebbi state.

\begin{tabular}{|l|l|l|l|l|l|l|l|}
\hline Option & Mean $(\overline{\mathbf{X}})$ & SD & N & Df & $\begin{array}{l}\text { Calculated } \\
\text { Value }\end{array}$ & $\begin{array}{l}\text { Critical } \\
\text { Value }\end{array}$ & Remark \\
\cline { 1 - 6 } Yes & 704.2 & 213.5 & 1150 & 4 & 1.35 & 2.78 & \\
\cline { 1 - 4 } No & 445.8 & 213.8 & & & & \\
\hline
\end{tabular}

$<0.05=2.78$

The above table is the analysis of the hypothesis that, there is no significant difference between the knowledge of the ICT and telecom among women/girls. The questionnaire items were used to address the findings. Since the calculated value as less than critical value, we accept the null hypothesis that, there no significant difference between the knowledge of ICT and telecom among women/ girls in Kebbi state. 
$\mathrm{H}_{0} 3$ : There is no significant relationship between the knowledge of ICT and acquisition of skills for life among women/girls in Kebbi state.

\begin{tabular}{|l|l|l|l|l|l|l|l|}
\hline Option & Mean $(\overline{\mathrm{X}})$ & SD & $\mathbf{N}$ & Df & $\begin{array}{l}\text { Calculated } \\
\text { Value }\end{array}$ & $\begin{array}{l}\text { Critical } \\
\text { Value }\end{array}$ & Remark \\
\hline YES & & & 1150 & 4 & 1.18 & 2.78 & \\
\hline NO & 599 & 243.9 & & & & & \\
\hline
\end{tabular}

$<0.05=2.78$

The above table is the analysis of the hypothesis that there is no significant relationship between then knowledge of ICT, Telecommunications and acquisition of skills for life among women/girls in Kebbi State. The questionnaire items were used to address the findings. Since the calculated value is less than the critical value we accept the null hypothesis that, there is no significant relationship between the knowledge of ICT and acquisition of skills for life among women/girls in Kebbi state.

\section{DISCUSSION}

The above tables analyses the findings based on the hypotheses stated in the research. The null hypothesis is accepted from all the tables above. It indicate the level of acceptance, since the calculated values are less than the critical values; there is no significant relationship between entrepreneurship, wealth creation and the knowledge of ICT and Telecommunications among women/girls in Kebbi State, there no significant difference between the Knowledge of ICT and telecom among women/girls in. Kebbi state and there is no significant relationship between the knowledge of ICT, Telecommunications and acquisition of skills for life among women/girls in Kebbi State.

\section{KEY FINDINGS}

The research sustained the following findings that;

- Girls/women in Kebbi State are lacking behind in ICT field as far as getting adequate / basic knowledge is concerned.

- Women/ Girl child in Kebbi State are not aware of ICT opportunities for them, which can help them acquire skills for life to become entrepreneurs and create wealth to support their self, families and the society at large.

- There are numerous possibilities for ICT to empower women, develop women entrepreneurs and create enabling environment for them to create wealth to support their families in the face of current economic hardship.

\section{RECOMMENDATIONS}

Based on the data interpreted, findings and conclusion of the study are as follows with recommendations The Government and relevant stakeholders in women/girl child education should increase access to training in scientific and technological fields for women/girl child in Kebbi state through Science and technology education which is the prerequisite for work in ICT world. 
Women should continue to be orientated so as to break their attitudinal barrier on ICT usage and the need to increase females enrolment in science oriented courses both at the secondary and tertiary education and the available opportunities therein.

Public campaigns should be organized by the relevant stakeholders in women/girl child education to sensitize and orient the women/girl child in Kebbi State on the numerous opportunities that are available in the ICT world and how this opportunities can help in empowering them to support their self, families and the Nation at large. Kebbi State Government should establish Government Technical Colleges for Gils in the State so as to help improve on the women/girl child education and acquire skills to empower them for life.

\section{CONCLUSION}

The need for ICT in our daily lives has been steadily increasing. Computers and the internet cannot be dismissed from the contemporary scene; even the importance of mobile phones and other ICT tools cannot be over emphasized. Thus it is impossible to imagine life today without digital media. ICT and telecommunications opportunities for women and girls provide ample chance for them to acquire skills for life, become entrepreneurs and create wealth to empower their self, support their families and the society at large in the face of high rate of unemployment, and struggling for survival in the male dominating world.

The society seems to perceive ICT sector as masculine dominated occupation. It is apparent that culturally certain occupations are preserved of women folk. It seems the women are not keeping pace with ICT but the men are taking upper hands in gaining more access to ICT sector. ICTs have the potential to combat poverty and foster sustainable development if appropriately deployed. If women are able to use it productively, they can substantially acquire skills for life, create labour, improve their lives and increase their income to support their families and the society at large. 


\section{REFERENCES}

[1] Drew, E. and F. G. Foster (eds.) (1994) Information Technology in Selected Countries, Tokyo: United Nations University Press.

[2] Adekomi A. A. (2007). The Challenges of an ICT Driven Instructional System in an Era of Depended Economy. A manuscript submitted for Publication, Obafemi Awolowo University, lle-lfe

[3] M.R. Bawa, D.D. Wisdom, A. B. Ismail, A.B. Abubakar, A. Aliyu, B. Ibrahim (2020): The Role Of Ict Education In Harnessing Human Capital Development In Africa, Anals Journal of Computer Science Series, Vol.17, Issue 2. 2020.

[4] S.A Shehu, D .D Wisdom, A.I Abubakar- ICT and Human Capital Development in Africa-Katsina Journal of Natural and Applied Sciences VOL.7, No. 1 March, 2018 (ISSN: 2141-0755).

[5] Butcher, N. (2003)Technological Infrastructure and use of ICT in education in Africa: An Overview. Paris: ADEA.

[6] Laudon, K.C., Trower, C.G., Laudon, J.P. (1994) Information Technology and Society. California: Wadsworth Publishing Company.

[7] Kao, R.W.Y., Kao, R. and Kao, K. 2002. Entrepreneurism. Imperial College Press: London.

[8] Wilson, K. (2004),-Entrepreneurship Education at European Universities and Business Schools: Results of a Joint Pilot Surveyll, presented at EISB/EFMD Conference in Turku Finland, September.

[9] Inegbenebor, A.U \&lgbinomwanhia, O.R. (2011).Entrepreneurship in a developing society.In F.C. Okafor. P.A. Isenmila\& A.U. Inegbenebor (2nd ed.), 3 - 11. Entrepreneurshipt: A practical approach. Benin City: Published by the Centre for Entrepreneurship Development, Uniben, B/C.

[10] Dinesh M. \& Maggie H. (2013). Wealth Creation : The ownership of valuable resources Deloitte \& Touche. All rights reserved. Member of Deloitte Touche Tohmatsu Limited Designed and produced by Creative Services at Deloitte, Johannesburg. (Siphiwe)

[11] An Efficient Authomated Revenue Generation Database Management System, Anals Journal of Computer Sciences Series, Vol. 17, Issue 1, 2020.

[12] Deans, P. C., and Kane, M. J. (1992) Information Systems and Technology, Boston, MA: PWS-Kent Publishing.

[13] Danso, A. E. D., Affum, E. A. K. and Hayffron-Acquah, J. B. (2012). The Challenges of Young ICT Entrepreneur in Developing Countries: Case Study - Ghana. International Journal of Computer Application, 45(21).

[14] World Bank (1999). World Bank Development Report: Knowledge for Development. World Bank: Washington D.C.

[15] INTEL (2011). The Path to growth: Accelerating entrepreneurship and innovation through ICT. INTEL White Paper.

[16] Curtain, R. (2003). Promoting Youth Income Generation Opportunities through Information and Communication Technologies (ICTs): Best Practices in Asia and the Pacific - A 2003 Update. International Conference of the Information Society.

[17] Alam, G. M. (2009). The Role of Science and Technology Education at Network Age population for Sustainable Development in Bangladesh through Human Resource Advancement. Academic Journals. Vol.4 (11).

[18] Oladunjoye, M. I. \& Audu, S. 2012) The Role of ICT in Entrepreneurship Development. Conference Paper Presented at 2nd Engineering Conference Organized by School of Engineering, Federal Polytechnic, Idah, Kogi State. 
[19] Olasunmi, O.O., Ayoola, T., Kareem, M.T. (2012) Evaluation of ICT Use Among Women Entrepreneurs in the Nigerian Government Industry. International Journal of Management and Business Studies.

[20] Weeks, J.R (2000) face of women Entrepreneurs. What we know today. Paper presented to second OECD conference on women Entrepreneurs in SMSs:

[21] Adeoji, J.A. (2005) Information Technology Investment in Nigeria Industry. The Progress So Far: Selected Papers for 204 Annual Conference, Ibadan: Nigerian Economic Society.

[22] Frenzel, C.W. (1996) Information Technology Management. Cambridge: Thomson Publishing Company.

[23] Scarborough, N.M. (2014). Essentials of entrepreneurship and small business management. (7th edition). Boston: Pearson.

[24] Wali, H.S. (2001) Information Technology and the Development of Northern States, Problems, Prospects and Plan for Action (A Paper Delivered on 24th April 2001) 